\title{
Kerukshahan Meninggalkan Shalat Jum'at \\ Pada Hari Raya Idain (Studi Takhrij Hadis)
}

\author{
Edriagus Saputra ${ }^{1}$, Zakiyah $^{2}$, Dian Puspita Sari ${ }^{3}$ \\ ${ }^{1,3}$ Institut Agama Islam Sumatera Barat (IAI Sumbar) Pariaman, Indonesia \\ ${ }^{2}$ Pascasarjana UIN Imam Bonjol, Padang, Indonesia \\ ${ }^{1}$ saputraedriagus@gmail.com, 22zakiyahhasan13@gmail.com, \\ 3dpuspitasari651@gmail.com
}

\begin{abstract}
This study aims to determine the quality of the hadith about Islamic remission of leaving Friday prayer in coincidence with Eid al-Fitr or Eid alAdha, both from the sanad and matan. This study is also to find out the hadith's meanings. By means of takhrij al-hadith and fiqh al-hadith methods, it is concluded that the hadith about Islamic remission of living Friday prayer in coincidence with the 'Idain is dhaif because the sanad, Iyas bin Ramlah and Israil got jarah of the Muslim scholars in all channels of the hadith's sanad. Meanwhile, for the understanding of Muslim scholars about the Islamic remission of leaving Friday prayer on the 'Idain, it is permissible as long as there are certain syar'i cases causing not to be able to perform Friday prayer, such as: rainy days, sickness, travelers, or being in the domicile far from the places that hold Friday prayer.
\end{abstract}

Keywords: Takhrij Hadith; the Islamic remission; Leaving Friday Prayer; Idain's Day

\section{Abstrak}

Penelitian ini bertujuan mengetahui kualitas hadis tentang kerukhshahan meninggalkan shalat Jum'at yang bertepatan dengan Hari Raya Idul Fitri atau Idul Adha, baik dari sisi sanad maupun matan. Juga untuk mengetahui pemaknaan terhadap hadis tersebut. Melalui metode takhrij al-hadits dan fiqh al-hadis, disimpulkan bahwa bahwa hadis tentang kerukhshahan meninggalkan shalat jum'at yang bertepatan pada hari raya 'Idain adalah dhaif, karena sanad Iyas bin Ramlah dan Israil terkena jarah para ulama di semua jalur sanad hadis. Sedangkan untuk pemahaman ulama tentang kerukhsahan meninggalkan shalat jum'at pada hari raya 'Idain, hal itu dibolehkan selama ada uzur syar'i yang menyebabkan tidak bisa melaksanakan shalat jum'at, seperti : hari hujan, sakit, musafir maupun jauh dari tempat pelaksanaan shalat Jum'at dari tempat domisili. 
Kata Kunci: Takhrij Hadis, Kerukhsahan; Meninggalkan Shalat Jum'at; Hari Raya Idain

\section{Pendahuluan}

Shalat Jum'at adalah perintah dari Allah SWT kepada orang mukmin untuk berkumpul dalam melaksanakan ibadah pada hari Jum'at yang dilaksankan dengan dua rakaat yang dikerjakan sesudah khutbah pada waktu Zhuhur. Hukum melaksanakan shalat Jum'at adalah wajib. ${ }^{1}$ Sebagaimana Allah SWT telah memerintahkan kepada orang-orang beriman untuk melaksanakan shalat Jum'at yang tercantum di dalam al-Qur'an pada surat alJumu'ah (62): 9

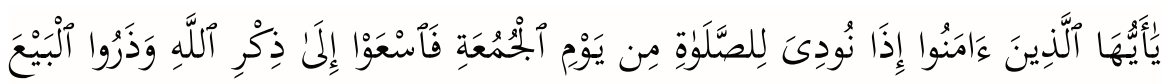

"Hai orang-orang beriman, apabila diseru untuk menunaikan shalat Jum'at, maka bersegeralah kamu kepada mengingat Allah dan tinggalkanlah jual beli..."

Dari ayat di atas yang mengindikasikan wajibnya shalat Jum'at bagi orang-orang yang beriman yaitu kalimat فاسعوا yang berarti berjalan, berlari atau bersegeralah ${ }^{3}$. Kalimat tersebut merupakan fi' $i l$ 'Amr, yaitu kalimat perintah yang menunjukkan kewajiban dalam melaksanakan shalat Jum'at bagi orang-orang yang beriman. Dan menurut Ibnu Katsir, bahwa kalimat سعى yang berarti berjalan cepat, tapi bukan berlari, maksudnya di sini berjalan dengan memperhatikan dan sungguh. Menurut Umar bin Khattab makna ayat tersebut, yaitu فامضوا إلى ذكرالله dengan makna berangkatlah kalian untuk mengingat Allah SWT. ${ }^{4}$ Maka wajib hukumnya bagi orang-orang yang beriman untuk menghadiri shalat Jum'at. Istilah wajibnya di sini mencakup pria dan wanita, baik yang bermukim di negeri tempat tinggalnya maupun yang musafir. Kewajiban di atas telah dijelaskan oleh Nabi SAW tentang siapa saja yang wajib melaksanakannya, sebagaimana

${ }^{1}$ Tim Ahli Tafsir, Shahih Tafsir Ibnu Katsir. (Penerjemah: Tim Pustaka Ibnu Katsir, Judul Asli: Al-Misbaahul Muniir fii Tahdziini Tafsiiri Ibni Katsiir), (Jakarta: Pustaka Ibnu Katsir, 2018), h., 107

${ }^{2}$ Departemen Agama RI, al-Qur'an dan Terjemahannya, (Bandung: Diponegoro, 2010), h., 554 .

3 Mahmud Yunus, Kamus Arab-Indonesia, (Jakarta: PT Mahmud Yunus Wa Dzurriyyah, 2010), h., 171.

${ }_{4}$ Tim Ahli Tafsir, op.cit., h.,107-108 
diriwayatkan oleh Abu Daud sebagai berikut:

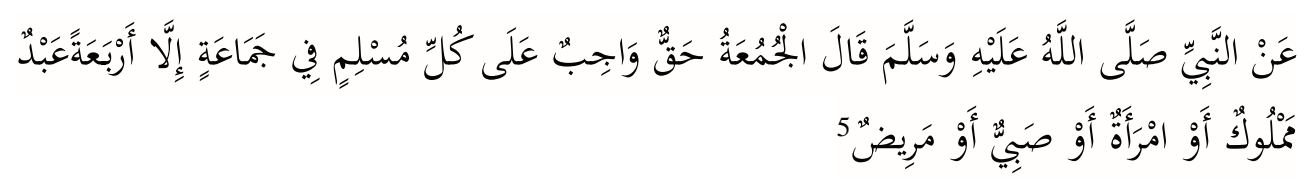

“....Dari Nabi shallallahu 'alaihi wasallam dia bersabda; "Jum'at adalah kewajiban bagi setiap muslim dengan berjama'ah, kecuali empat golongan, yaitu; hamba sahaya, wanita, anak-anak dan orang yang sakit."(HR. Abu Daud)

Hadis di atas menjelaskan tentang setiap orang berkewajiban dalam melaksanakan shalat Jum'at, terkecuali hamba sahaya, perempuan, anak-anak dan orang sakit. Shalat Jum'at dinilai sebagai pengganti shalat Zhuhur, karena itu, bagi muslim yang telah melaksanakan shalat Jum'at tidak lagi diwajibkan atau dianjurkan dalam pelaksanaan shalat Zhuhur, dan dua khutbah dari shalat Jum'at dinilai sebagai pengganti dua raka'at dari shalat Zhuhur.

Shalat Jum'at merupakan ibadah yang dilaksanakan satu kali dalam satu minggu, yaitu pada hari Jum'at. Namun, jika hari 'Idain bertepatan pada hari Jum'at, maka para ulama berbeda berpendapat, sehingga ada sebagian para ulama berpendapat kewajiban shalat Jum'at otomatis gugur dan digantikan dengan shalat Zhuhur seperti biasa. ${ }^{6}$ Sebagaimana Rasulullah SAW telah menjelaskan di dalam sabdanya yang diriwayatkan oleh al-Nasa'i sebagai berikut:

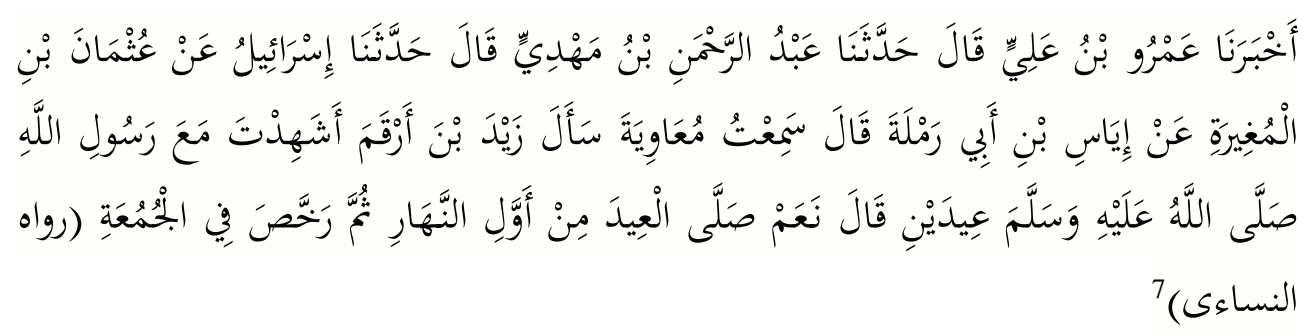

"'Amr bin 'Ali telah mengabarkan kepada kami, dia berkata; 'Abdurrahman bin Mahdi telah menceritakan kepada kami dia berkata; Israil telah

5 Al-Imam al-Hafiz Abu Daud Sulaiman bin al-As'as al-Sajistaniy, Sunan Abi Daud, (Bairut: Darl al-Kitab al-Ilmiyah, 1426 H), bab., Shalat., h., 177.

${ }^{6}$ Abdul Aziz Muhammad Azzam, dkk, Fiqh Ibadah, (Jakarta: Amzah, 2013), Cet. ke-3., h.,315.

${ }^{7}$ Al-Imam Al-Hafiz Abi Abdurrahman Ahmad bin Su'ib bin Ali al-Khurasaniy al-Nasa'i, Sunan Nasa'i, (Beirut: Darl Al-Kitab Al-Ilmiah, 1426) h., 191. 
menceritakan kepada kami dari 'Utsman bin Al Mughirah dari Iyas bin Abu Ramlah dia berkata; aku mendengar Mu'awiyah bertanya kepada Zaid bin Arqam, 'Apakah engkau pernah mengerjakan shalat dua hari raya bersama Rasulullah shallallahu 'alaihi wasallam? ia menjawab, 'Ya, Nabi SAW shallallahu 'alaihi wasallam mengerjakan shalat hari raya pada permulaan siang (pagi hari), lalu Nabi SAW memberi rukhshah kewajiban Jumat (boleh melakukannya, boleh juga tidak)." (HR. Al-Nasa'i) $)^{8}$

Hadis di atas menjelaskan, bahwa jika hari Jum'at bertepatan pada hari 'Idain, maka Rasulullah SAW memberikan keringanan (rukhshah) kepada kaum muslimin dalam melaksanakan shalat Jum'at, yaitu boleh meninggalkan atau melaksanakannya.

Ibn Quddamah mengemukakan dalam kitabnya al-Mughni "Jika hari raya jatuh pada hari Jum'at, maka gugurlah kewajiban menghadiri Jum'atan bagi yang telah melaksanakan shalat 'Id, kecuali Imam. Karena imam tidak gugur shalat Jum'atnya disebabkan dia akan mengimami orang yang akan melaksanakan shalat Jum'at, terkecuali tidak ada jama'ah yang hendak melaksanakan shalat Jum'at. ${ }^{9}$

Seiringan dengan penjelasan yang telah dipaparkan oleh peneliti, bahwa adanya pertentangan antara makna hadis dengan makna ayat al-Qur'an pada surat al-Jumu'ah:9, maka peneliti menganggap permasalahan tersebut harus dikaji dan dicarikan solusinya, sehingga tidak terjadi kesalahpahaman dalam memahami makna hadis, makna al-Qur'an maupun adanya kebolehan dalam meninggalkan Shalat Jum'at pada hari raya Idain.

Jika dirujuk dengan kajian literatur terdahulu, terdapat beberapa penelitian yang mengkaji tentang shalat jum'at dan shalat hari raya idain melalui bantuan media online baik dalam bentuk jurnal maupun artikel, diantaranya, yaitu : Pertama, Hukum Salat Jum'at bertepatan pada Hari Raya (Studi Komparatif antara Mazhab Syafi'i dan Mazhab Hanbali). Penelitian ini dalam bentuk skripsi mahasiswa Prodi Perbandingan Mazhab, Fakultas Syari'ah dan Hukum, UIN Ar Raniry Darussalam Banda Aceh, tahun 2018). Penelitian tersebut menjelaskan tentang hukum menurut imam mazhab syafi' $i$ dan mazhab hanbali yang akan mendapatkan sebuah kesimpulan hukum

\footnotetext{
${ }^{8}$ Al-Imam al-Hafiz Abu Daud Sulaiman bin al-as'as al-Sajataniy, op. cit., h.177.

${ }^{9}$ Ibid., h. 77.
} 
pelaksanaannya dari kedua mazhab tersebut. ${ }^{10}$ Kedua, Pemahaman Hadis 'Idain di Hari Jum'at (Pendekatan Ma'anil Hadis). Penelitian ini dalam bentuk skripsi Mahasiswa Tafsir Hadis, Fakultas Ushuuddin dan Humaniora, UIN Walisongo Semarang, tahun 2017). Penelitian tersebut menjelaskan pemahaman ulama terkait hadis Idain di Hari Jum'at dengan menggunakan pendekatan Ma'anil Hadis dan kesimpulan dari penelitian tersebut pemahaman ulama terkait hadis idain di hari jum'at. ${ }^{11}$ Ketiga, Studi Kritik Hadis tentang Melaksanakan Shalat Jum'at pada Waktu Hari Raya. Penelitian ini dalam bentuk jurnal yang diterbitkan oleh Jurnal Ilmiah Keislaman, Program Pascasarjana UIN SUKA, atas nama Khairuddin. Penelitian ini menjelaskan tentang studi kritik hadis tentang pelaksanaan shalat Jum'at pada Waktu Hari Raya sehingga memunculkan sebuah hukum dalam pelaksanaannya. $^{12}$

Sedangkan tujuan kajian ini mengupas kualitas hadis dan pemahaman ulama yang terfocus pada hadis-hadis tentang kerukhsahan meninggalkan shalat Jum'at yang bertepatan pada hari raya Idain yang pada akhir research ini akan mendapatkan kualitas hadis dan pemahaman ulama terkait hadis tersebut. Dalam melakukan penelitian terhadap artikel ini, penulis menggunakan metodologi studi library research dan untuk mendapatkan kesimpulan terhadap penelitian ini, penulis melakukan takhrij hadis dan analisis data terkait hadis-hadis Kerukhsahan meninggalkan shalat Jum'at bertepatan pada hari raya Idain. Dalam mendapatkan pemahaman ulama terhadap adanya keringanan meninggalkan shalat Jum'at yang bertepatan pada hari Idain, maka peneliti mengambil pemahaman para ulama melalui syarahsyarah kitab hadis maupun literatur yang mendukung lainnya. Bahan yang menjadi rujukan utama dalam penelitian ini, yaitu kitab takhrij hadis, kitab kutubus tis'ah (Kitab Ulama yang sembilan) dan kitab syarah hadis terkait.

\section{Pembahasan}

10 Amnu Rizal, Hukum Salat Jum 'at bertepatan pada Hari Raya (Studi Komparatif antara Mazhab Syafi 'i dan Mazhab Hanbali), , UIN Ar Raniry Darussalam Banda Aceh, tahun 2018. https://repository.ar-raniry.ac.id.

${ }^{11}$ Muhammad Zuhdi Anwar, Pemahaman Hadis 'Idain di Hari Jum'at (Pendekatan Ma'anil Hadis), skripsi Mahasiswa Tafsir Hadis, Fakultas Ushuuddin dan Humaniora, UIN Walisongo Semarang, tahun 2017. https://core.ac.uk.

${ }^{12}$ Khairuddin, Studi Kritik Hadis tentang Melaksanakan Shalat Jum'at pada Waktu Hari Raya, Program Pascasarjana UIN SUSKA. Al-Fikra: Jurnal Ilmiah Keislaman, Vol.11, No.1 (2012). https://ejournal.uin-suska.ac.id. 


\section{Metode Penelusuran Hadis}

Penelusuran sanad hadis bertujuan untuk menemukan teks-teks hadis yang memiliki makna senada dari kitab-kitab hadis. Hadis Nabi SAW yang telah terkodifikasi oleh mukharrij hadis berjumlah ratusan bahkan ribuan. Jika ditelusuri satu persatu dari kitab-kitab hadis yang ada, maka akan sangat sulit, untuk itu agar lebih mudah memahaminya, maka penulis membagi beberapa tahap dalam menganalisis kuantitas sanad hadis tersebut. Adapun hadis yang penulis teliti adalah:

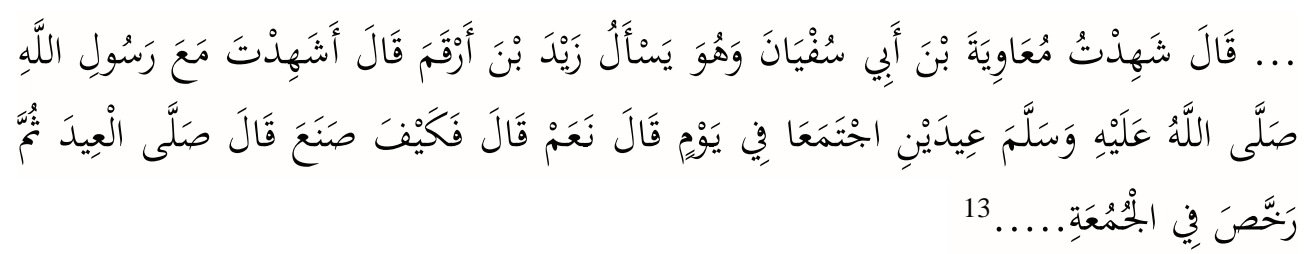

Langkah penulis selanjutnya yaitu mencari bagian penggalan atau potongan matan hadis pada kitab al-Mu'jam al-Mufahras li al-Fazh al-Hadits al-Nabawiy karya A. J. Wensinck. ${ }^{14}$

Dalam melakukan pencarian hadis, maka penulis menentukan terlebih dahulu kata kuncinya (keyword) yang terdapat di dalam matan hadis tersebut, sehingga mudah melakukan pencarian hadis yang dicari. Kata kunci yang penulis tetapkan dalam pencarian hadis tersebut adalah رخص dan شهر d رخصا. Penulis memilih kata رخص karena hadis yang penulis teliti berkaitan dengan kerukhshahan sebagai tema pokok dalam penelitian ini.

Dengan menggunakan matan hadis di atas, maka penulis mencari hadis tersebut dengan menggunakan kata kunci yang telah penulis tetapkan. Maka penulis menemukan kata شهـ di dalam kitab Mu'jam al-Mufaras sesuai dengan hadis yang penulis cari dengan informasi lafal hadisnya, yaitu

$$
\text { شهدت معاوية يسأل زيد بن ارقم اشهدت... دى: الصلاة:00 ب } 15
$$

${ }^{13}$ Al-Imam al-Hafiz Abu Daud Sulaiman bin al-Asy'ats al-Sajistaniy, Sunan Abi Daud, (Bairut: Dar al-Kutb al-Ilmiyah, 1426 H)., h., 177.

14 A.J. Wensinck, al-Mu'jam al-Mufahras li al-Fazh al-Hadits al-Nabawiy al-Kutub al-Sittah wa 'am musnad al-Darimi wa muwatta' al-Malik wa Musnad Ahmad bin Hanbal, (Istanbul: Darul al-Dakwah, 1986)., Juz., ke-3

15 A.J. Wensinck, Op.cit.,Juz., ke-16., h., 187. 
Sedangkan dengan menggunakan kata رخص di dalam kitab Mu'jam al-Mufaras, yaitu

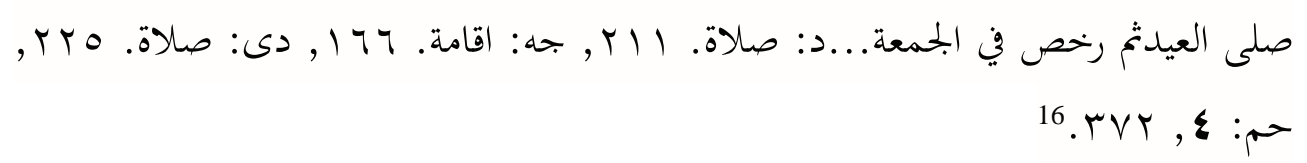

Dari petunjuk kitab Mu'jam tersebut dapat diketahui bahwa: Huruf د adalah kode untuk Abu Daud, menunjukkan bahwa hadis yang terdapat pada Sunan Abu Daud, kitab صلاة kata ini menunjukkan bahwa hadis tersebut terdapat di dalam kitab Shalat, nomor bab 211. Pada huruf kedua جه menunjukkan bahwa hadis tersebut terdapat di dalam Sunan Ibn Majah, kitab kata ini menunjukkan bahwa hadis tersebut terdapat di dalam bab iqomah, nomor hadis 166. Petunjuk ketiga yaitu huruf دي إد menunjukkan bahwa hadis tersebut terdapat di dalam Sunan Darimi, bab صلاة kata ini menunjukkan bahwa hadis tersebut terdapat di dalam bab Shalat, nomor hadis 225. Dan petunjuk keempat yaitu huruf menunjukkan bahwa hadis tersebut terdapat di dalam Musnad Ahmad bin Hanbal, hadis tersebut terdapat pada jilid ke-4 halaman 372.

Jadi, dapat disimpulkan bahwa hadis-hadis terkait kerukhsahan dalam pelaksanaan shalat Jum'at bertepatan pada hari Idain dengan menggunakan dua kata kunci ditemukan hadis tersebut di beberapa kitab hadis yang terkumpul dalam kutubus tis'ah, diantaranya : Kitab sunan Abi Daud, Kitab sunan Ibn Majah, Kitab Sunan Ad Darimi dan Kitab Musnad Ahmad bin Hanbal.

\section{Hadis-hadis tentang Kerukhsahan Meninggalkan Shalat Jum'at pada Hari Raya Idain}

a. Riwayat Abu Daud

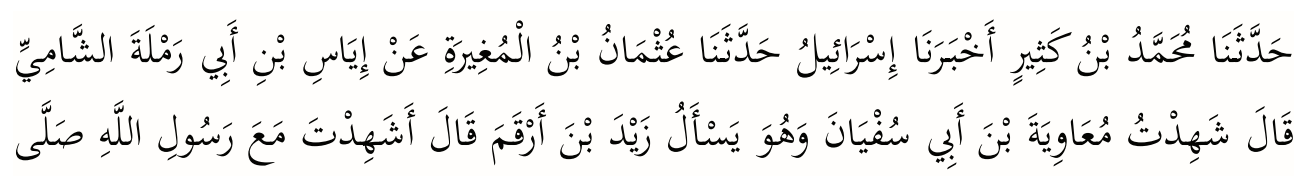

16 Ibid., Juz., ke-2., h., 241. 


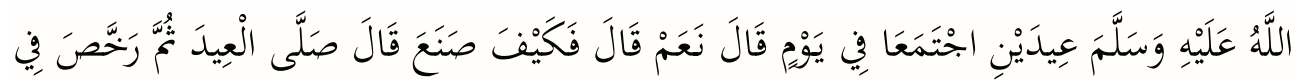

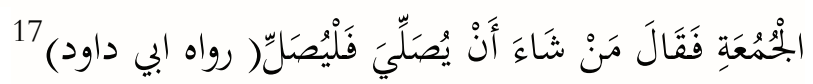

b. Riwayat Ibn Majah

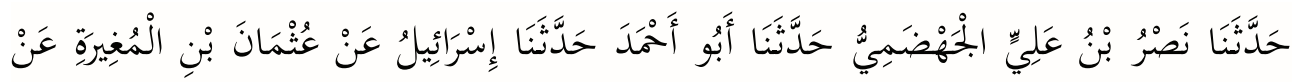

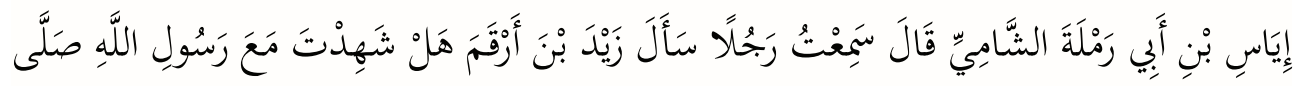

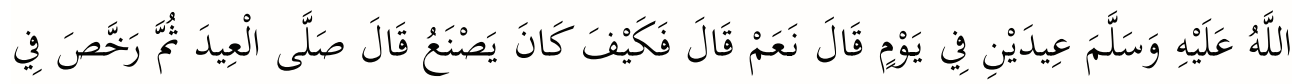

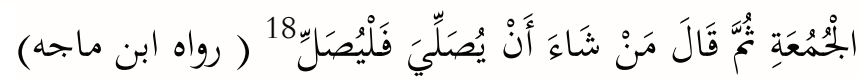

c. Riwayat Ad Darimi

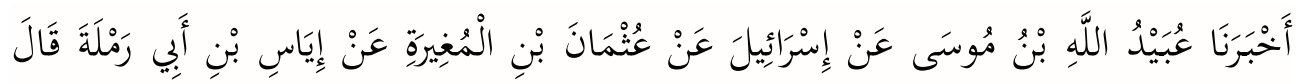

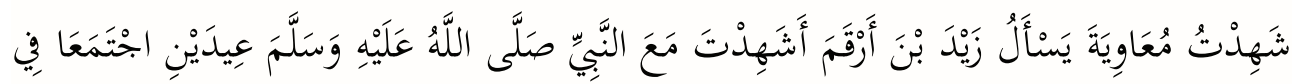

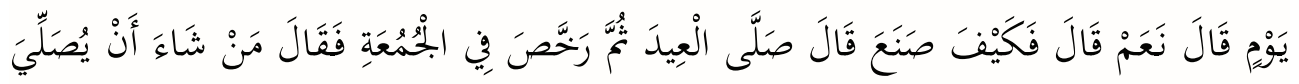

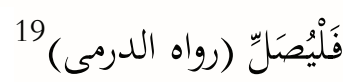

\section{d. Riwayat Ibn Ahmad bin Hanbal}

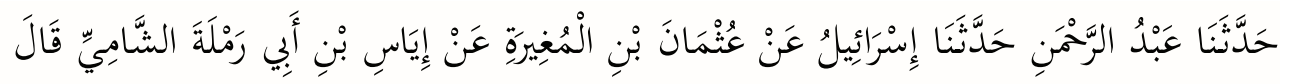

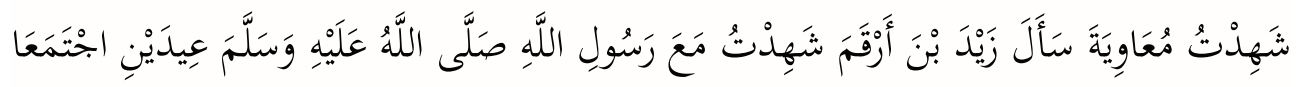

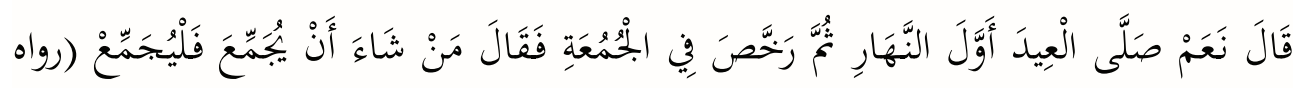
20 (احم)

17 Al-Imam al-Hafiz Abu Daud Sulaiman bin al-Asy'ats al-Sajistaniy, loc. cit.

18 Al-Hafidz Abi Abdullah Muhammad bin Yazid al-Qazwiniy, Sunan Ibn Majah, (Bairut: Dar al-Kutb al-Ilmiah, 1426)., h., 212.

${ }^{19}$ Al-Amamar Abi Muhammad Abdullah bin Bahar Amr al-Darimi, Sunan al-Darimi , (Bairut: Dar al-Fikr, 1426), Juz., 1-2., h., 270.

${ }^{20}$ Ahmad bin Muhammad bin Hanbal bin Hilal bin Asad bin Idris, Musnad Ahmad bin Hanbal, (Bairut: Dar al-Fikr, 1426), Juz., ke-4., h., 372. 
Edriagus Saputra, et.al: Kerukhshahan Meninggalkan Shalat Jum'at... | 245

\section{Skema Sanad Hadis}

a. Riwayat Sunan Abu Daud

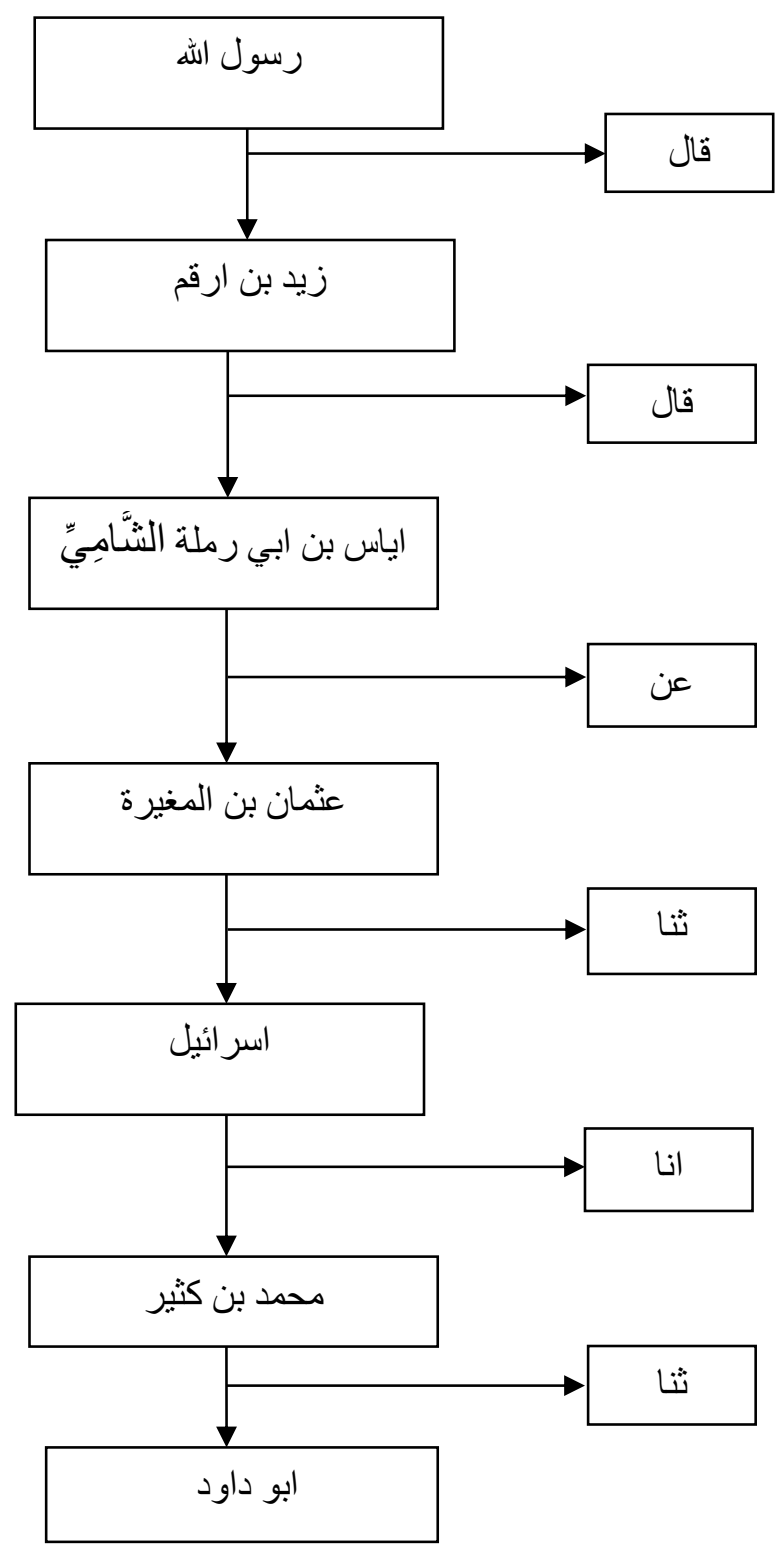




\section{b. Riwayat Ibn Majah}

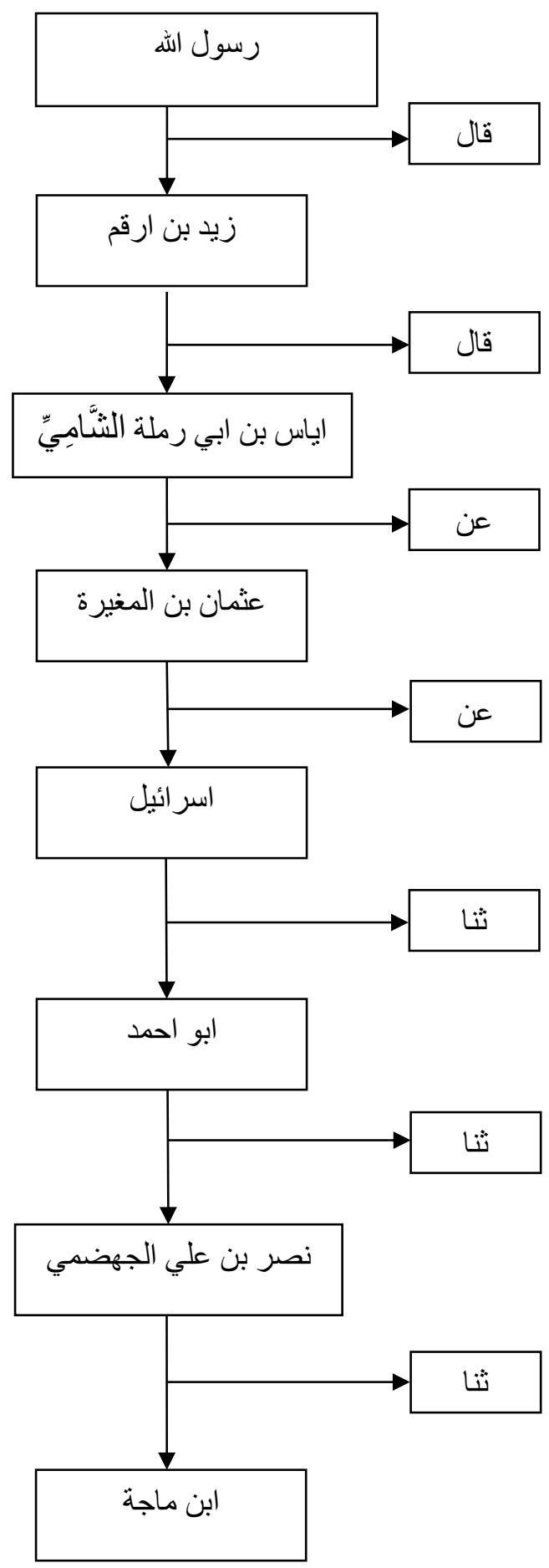


c. Riwayat Ad Darimi

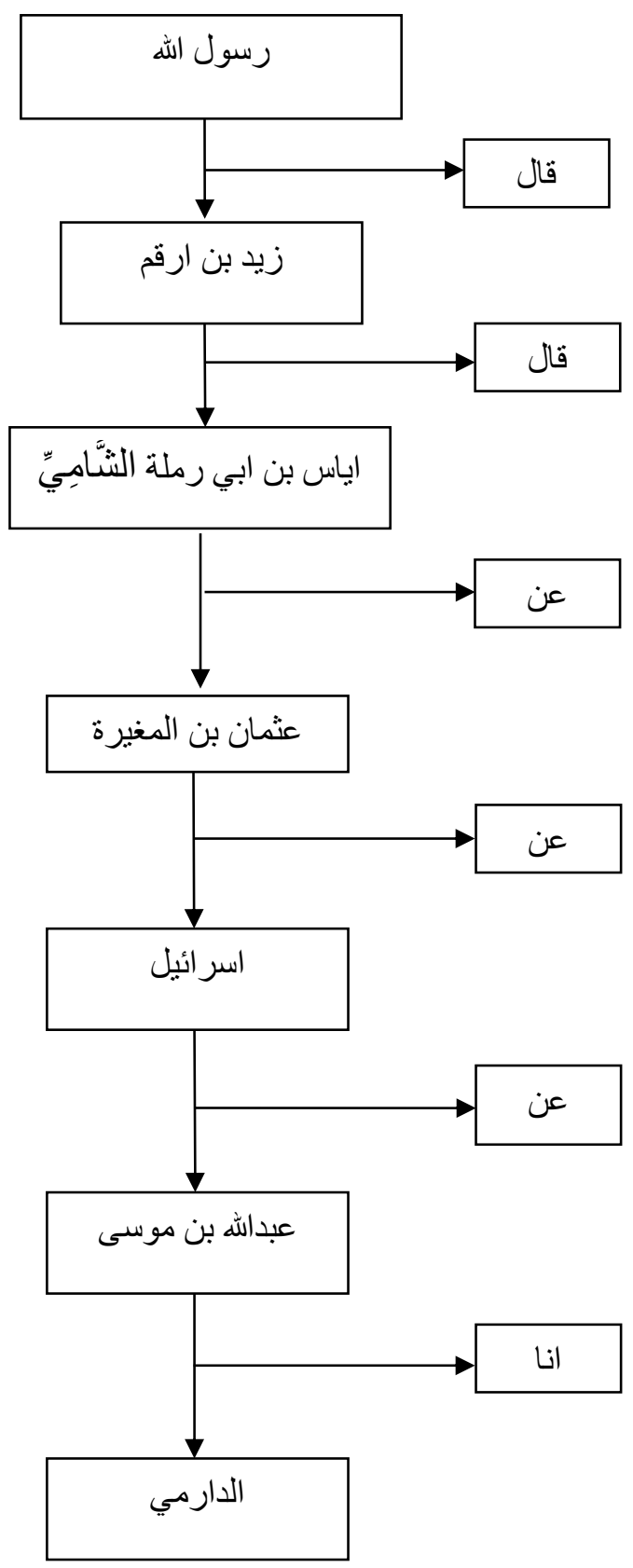


d. Riwayat Ibn Ahmad bin Hanbal

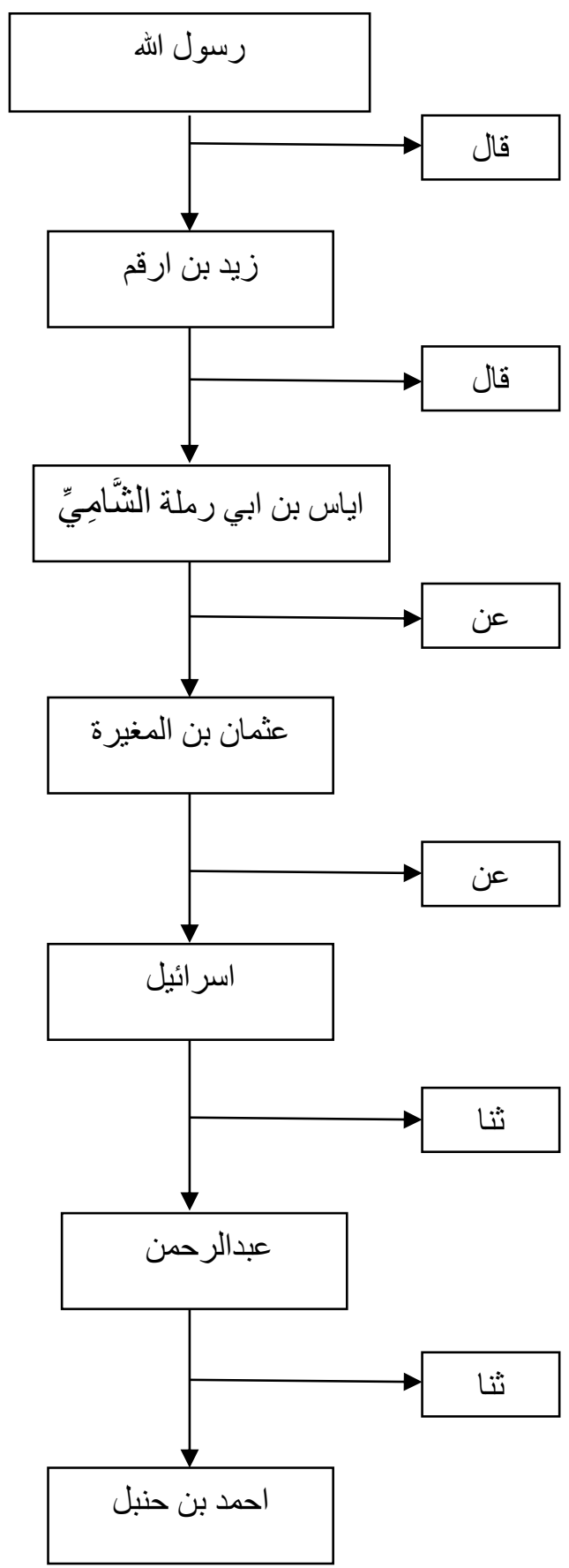


e. Ranji Sanad Hadis Gabungan

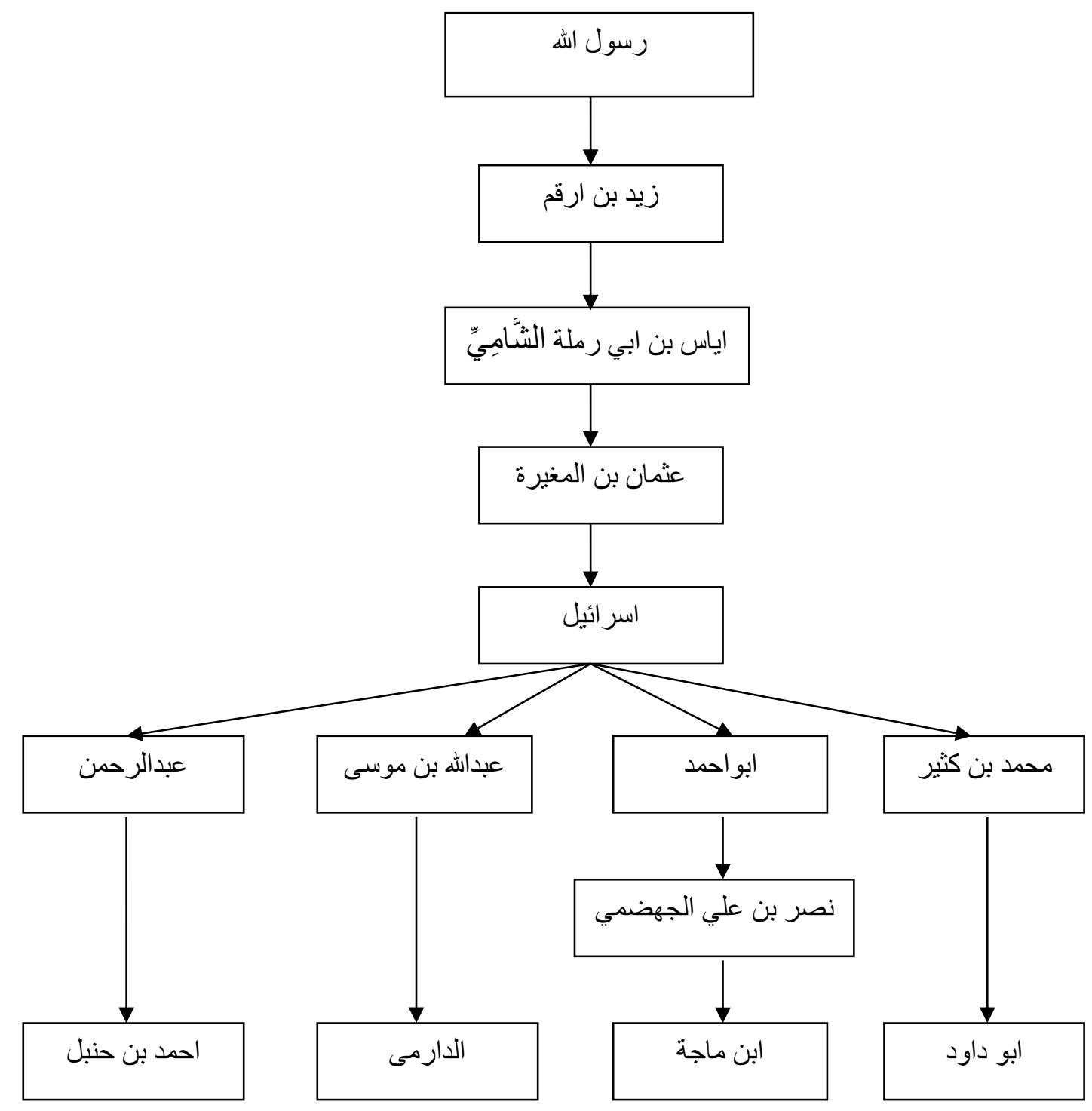

\section{Takhrij Sanad dan Matan Hadis}

Berdasarkan penelitian penulis berkaitan sanad hadis tentang kerukhsahan shalat Jum'at bertepatan pada hari raya 'Idain dari jalur Abu Daud, maka dapat penulis simpulkan, bahwa sanad hadis tersebut adalah dha'if, karena adanya penilaian ulama yang men-jarh pada sanad hadis tersebut, yaitu: 
a. Iyas bin Ramlah al-Syamiy ${ }^{21}$ dengan jarahnya dari para ulama, yaitu: penulis menemukan informasi ia tidak langsung berguru kepada Zaid bin Arqam dan Muawiyah bin Abi Sufyan, ${ }^{22}$ tetapi ia hanya mendengar hadis tersebut melalui Muawiyah bin Abi Sufyan bertanya kepada Zaid bin

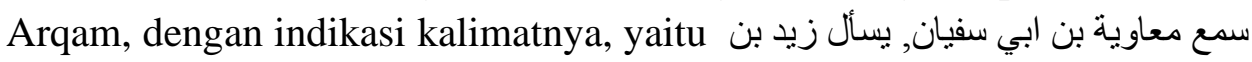
( ارقم yang berarti dia mendengar Muawiyah bin Abi Sufyan, dia ${ }^{23}$ ) (Muawiyah) bertanya kepada Zaid bin Arqam dan Berdasarkan informasi tentang keadilan dan ke-dhabith-an Iyas bin Abi Ramlah terdapat ta'arudh (pertentangan antara jarh dan ta'dil) karena ada ulama yang menilai beliau dengan prediket majhul. ${ }^{24}$ Disebabkan yang meriwayatkan hadis darinya hanya Usman bin al-Mughirah serta tidak adanya ulama lain yang men-jarh beliau, dan beliau ini termasuk kepada majhul al-'ain, yaitu suatu hadis yang di dalam sanadnya ada seorang periwayat yang hanya seorang periwayat lain saja meriwayatkan daripadanya serta tidak ada seorang ulama men-jarh-nya. ${ }^{25}$ Dengan demikian, dapat penulis simpulkan bahwa Iyas bin Abi Ramlah adalah majhul, majhul adalah perawi yang tidak diketahui atau dikenali baik dari segi identitas, kredibilitas dan jati dirinya, ${ }^{26}$ dengan demikian bararti Iyas bin Abi Ramlah dinilai sebagi seorang yang tidak adil dan tidak dhabith.

b. Israil bin Yunus bin Abi Ishaq Al-Hamadiy al-Sabi'iy dan lebih dikenal dengan nama Abu Yusuf. ${ }^{27}$. Jarahnya dari para ulama terhadap Israil, , yaitu Ijla menilainya ثقة صدوق 29 ثقب sedangkan menurut Ibn Madiniy, Israil adalah ضعيف, Nasa'i, Isra'il adalah ليس به بأس بل بل

21 Al-Hafidz Jamaluddin Abi al-Hajjaj Yusuf al-Maziy, Tahzib al-Kamal fi Asma'i al-Rijal, (Beirut: Darl Al-Fikri, 1426)., Juz.,ke-2, h., 188

${ }^{22}$ Al-Imam Al-Hafidz Abi Muhammad Abdurrahman Abi Hatim Muhammad bin Idris al-Tamim al-Hanzality al-Raziy, Op.cit., Juz., ke-2., h.,205

${ }^{23}$ Al-Hafidz Jamaluddin Abi al-Hajjaj Yusuf al-Maziy, Op.cit.,h., 364

${ }^{24}$ Abi Abdillah Muhammad bin Ahamd bin Usman al-Zahabiy, Mizan I'tidal, (Beirut: Darl Al-Fikri, 1426)., Juz., ke-1.,h.,282

${ }^{25}$ A. Qadir Hassan, Ilmu Mushthalah Hadits, (Bandung: CV Diponegoro, 1996), Cet., ke-7., h., 182.

${ }^{26}$ Ibid.

${ }^{27}$ Al-Hafidz Jamaluddin Abi al-Hajjaj Yusuf al-Maziy, op.cit., Juz., ke-2., h., 100

${ }^{28}$ Ibid., h., 106.

${ }^{29}$ Ibid.

${ }^{30}$ Abi Abdillah Muhammad bin Ahmad bin Usman al-Zahabiy, op. cit., Juz., I., h., 209.

\footnotetext{
${ }^{31}$ Al-Hafidz Jamaluddin Abi al-Hajjaj Yusuf al-Maziy, op. cit., h., 32.
} 
tentang ke-adil-an dan ke-dhabith-an Israil bin Yunus terdapat ta'arudh (pertentangan antara jarh dan $t a^{\prime}$ 'dil) dengan arti kata ada yang menilai jarh dan ada pula yang menilai ta'dil, karena adanya ulama yang men-jarh beliau dengan prediket dhaif. Dalam penyelesaian permasalahan ini, menurut para ulama yaitu mendahulukan jarh daripada ta'dil, meski yang men-ta'dil lebih banyak daripada yang men-jarh-nya. Karena yang mentarjih mengetahui apa yang tidak diketahui oleh yang men-ta'dil, dan ini pendapat yang diperpegangi oleh jumhur ulama. ${ }^{32}$ Maka penulis berkesimpulan bahwa beliau adalah seorang yang dhaif.

Begitu pula hadis yang diriwayatkan oleh Ibn Majah, al-Darimi dan Ahmad bin Hanbal juga berkualitas dhaif, karena Iyas bin Abi Ramlah dan Israil bin Yunus yang terkena jarh juga terdapat pada jalur sanad mereka, berarti semua jalur sanad hadis tentang kerukshsahan shalat Jum'at bertepatan pada hari 'Idain adalah dhaif.

Setelah melakukan takhrij hadis dari sanadnya, maka dapat disimpulkan, bahwa hadis yang diriwayatkan melalui jalur Abu Daud, Ibn Majah, Ad-Darimi dan Ahmad bin Hanbal adalah dhaif dari segi sanad maupun matan, karena pada sanadnya terdapat sanad yang terkena jarh, yaitu Israil bin Yunus dan Iyas bin Abi Ramlah al-Syamiy dan pada matan hadis adanya pertentangan dengan ayat al-Qur'an surah al-Jumu'ah (62): 9, serta hadis tersebut menjelaskan adanya kebolehan untuk meninggalkan shalat Jum'at pada hari itu, sebagaimana adanya uzhur yang membolehkan dalam meninggalkan shalat Jum'at ketika hari hujan.

\section{Analisa Kehujjahan Hadis}

Setelah penulis teliti melalui takhrij hadis tentang kerukhsahan shalat Jum'at bertepatan pada hari 'Idain baik dari segi sanad maupun matan hadis yang diriwayatkan oleh Abu Daud dan 3 (tiga) jalur lainnya, yaitu Ibn Majah, al-Darimi dan Ahmad bin Hanbal, dengan memperhatikan rambu-rambu yang telah dikemukan oleh para ulama mengenai kaidah-kaidah ke-shahih-an suatu hadis, baik persyaratan sanad maupun persyaratan matan hadis, maka dapat diambil garis tengahnya, bahwa hadis yang menerangkan tentang kerukhsahan shalat Jum'at bertepatan pada hari 'Idain dalam pelaksanaannya adalah dha' if

${ }^{32}$ Muhammad 'Ajjaj al-Khathib, Ushul Hadits: Ulumul wa Mushthalahuhu. (Bairut: Darl Al-Fikri, 1429)., h., 241. 
serta dari segi matannya juga dha'if karena nampak adanya bertentangan dengan ayat al-Qur'an surat al-Jumu'ah (62): 9. Untuk mendapatkan suatu kesimpulan yang utuh, maka peneliti akan mencari solusi dari pemahaman ulama terhadap pelaksanaan hadis tersebut, sehingga akan mendapatkan sebuah hukum yang dapat diperpengangi dalam beramal.

\section{Pemahaman Ulama terhadap Hadis}

Asbab al-wurud hadis merupakan suatu peristiwa yang menyebabkan hadis tersebut disabdakan oleh Rasulullah SAW. Melalui asbab al-wurud hadis, maka hadis tersebut dapat diketahui penyebab yang melatarbelakangi suatu hadis itu muncul, sehingga dapat dipahami maksud dan tujuan dari hadis-hadis Rasulullah SAW. Begitu juga dengan hadis yang berkaitan dengan shalat Jum'at pada hari 'Idain, dengan mengkaji asbab al-wurud hadis tentang shalat Jum'at pada hari 'Idain, maka dapat diketahui penyebab yang melatarbelakangi hadis tersebut muncul. Namun, berdasarkan penelitian yang penulis lakukan berkaitan asbab al-wurud hadis-hadis tentang shalat Jum'at pada hari raya 'Idain melalui kitab Asbab Wurud al-Hadits yang dikarang oleh al-Imam al-Syuyutiy, kemudian di-tahqiq oleh Dr. Yahya Ismail. ${ }^{33}$ Setelah penulis telusuri kitab tersebut penulis tidak menemukan asbab alwurud hadis yang berkaitan dengan shalat Jum'at pada hari raya 'Idain. Namun, dalam syarah Muslim karya Imam al-Nawawiy dapat diketahui asbab al-wurud hadis ini berlaku bagi umat Islam yang tempat tinggalnya diperkampungan, perdesaan serta jauh dari kota. Dalam syarah Muslim, Imam al-Nawawiy menjelaskan, bahwa rukhshah ini berlaku bagi umat Islam yang jauh tinggalnya dari perkotaan, sehingga selesai melaksanakan shalat 'Idain, mereka kembali ke kampung halamannya dan bergembira dengan keluarganya, serta berlaka ke-rukhshah-an dalam meninggalkan shalat Jum'at, namun tetap wajib melaksanakan shalat Zhuhur sebagaimana kewajiban umat Islam yang tidak melaksanakan shalat Jum'at. ${ }^{34}$

Berdasarkan penelitian penulis terhadap hadis yang diriwayatkan oleh Abu Daud, Ibn Majah, ad-Darimi dan Ibn Ahmad bin Hanbal, bahwa hadis dari Iyas bin Ramlah al-Syamiy dan Israil bin Yunus berkaitan dengan hadishadis tentang Kerukhsahan shalat Jum'at bertepatan pada hari 'Idain adalah

\footnotetext{
${ }^{33}$ Al-Hafidz Jalaluddin As Syuyutiy, Asbab Wurud al-Hadits, (Pentahqiq: Dr. Yahya Ismail) (Beirut: Darl Al-Kutub, 1985)

${ }^{34}$ Abu Ishaq Ibrahim bin Ali bin Yusuf al-Fairuzabadi Asy-Syirazi Asy-Syafi'i, al-Muhazzab fi Fiqh Imam al-Syafi 'i, (Beirut: Al-Kutub al-Ilmiah, tt)., Juz., ke-1
} 
berstatus dha'if baik dari segi sanad dan matan. Dalam rangka untuk mengetahui tentang pemahaman ulama berkaitan dengan hadis-hadis tentang kerukhsahan shalat Jum'at bertepatan pada hari raya 'Idain, maka penulis akan memaparkan pemahaman ulama, sebagai berikut:

Menurut al-Hafiz Ibn Qayim al-Jauziy dalam kitabnya 'Aun al-Ma'bud (Syarah Sunan Abu Daud), bahwa shalat Jum'at yang bertepatan pada hari raya 'Idain, yaitu boleh melaksanakan shalat Jum'at dan boleh juga meninggalkannya. Namun bagi orang yang tidak melaksanakan shalat Jum'at yang bertepatan pada hari raya Idain dengan mengamalkan keringanan/rukhshah tersebut, maka ia wajib melaksanakan shalat Zhuhur, karena shalat Jum'at pengganti dari shalat Zhuhur, tetapi kebanyakan dari umat Islam memahami hadis ini, bahwa bolehnya meninggalkan shalat Jum'at dan shalat Zhuhur. ${ }^{35}$

Syaikh Faishal bin Abdul Aziz Ali Mubarak juga menjelaskan dalam bukunya yang masyhur, yaitu Bustanul Ahbari Mukhtashari Nail al-Authar, bahwa ke-rukhshah-an yang terdapat pada hadis shalat Jum'at yang bertepatan pada hari raya 'Idain menunjukkan, bahwa shalat Jum'at pada hari raya 'Idain boleh ditinggalkan, karena ke-rukhshah-an di sini dipahami dengan sifat yang umum dan berlaku bagi setiap orang, tetapi tidak menggugurkan kewajiban seseorang dalam melaksanakan shalat Zhuhur. ${ }^{36}$

Ahmad bin Hanbal juga berpendapat, bahwa shalat Jum'at yang bertepatan pada hari raya 'Idain, maka tidak wajib hukumnya melaksanakan shalat Jum'at baik bagi penduduk yang tinggal di kota maupun di desa, dan gugurlah kewajiban dalam melaksanakan shalat Jum'at disebabkan, karena shalat Jum'at yang bertepatan pada hari raya 'Idain, namun tetap wajib hukumnya melaksanakan shalat Zhuhur. ${ }^{37}$

Berbeda dengan pendapat di atas, Imam al-Syafi'i dan mayoritas ulama fiqh mengatakan, bahwa shalat Jum'at tetap wajib hukumnya walaupun bertepatan pada hari 'Idain berdasarkan keumuman ayat dan banyak riwayat yang menunjukkan wajibnya dalam melaksanakan shalat Jum'at. Lain dari itu,

35 Al-Hafizh Ibn Qayim al-Jauziyah, Aun al-Ma'bud Syarah Sunan Abi Daud, (Bairut: Dar al-Fikr, 1426), Juz., ke-3., h., 407.

${ }^{36}$ Faishal bin Abdul Aziz Ali Mubarak, Ringkasan Nailul Authar (judul asli: Bustan al-Ahbari Muhthashari Nail al-Authar). (Penerjemah: Amir Hamzah Fakhruddin, dkk), Jakarta Selatan: Pustaka Azzam, 2006, Cet., II., h., 77.

37 Al-Hafizh Ibn Qaim al-Jauziyah, Op.cit Juz., ke-1., h., 409. 
bahwa shalat 'Idain dan shalat Jum'at adalah kewajiban yang tidak gugur karena melaksanakan salah satunya, kecuali ada uzhur yang memperbolehkan tidak melaksanakan shalat Jum'at. Namun ke-rukshah-an tersebut hanya berlaku bagi orang yang berada di kampung yang jauh dari tempat pelaksanaan shalat 'Idain. ${ }^{38}$

Dan Imam Abu Hanifah sependapat dengan Imam al-Syafi'i, bahwa hukum shalat Jum'at tersebut tetap wajib hukumnya, dan ke-rukhshah-an tersebut hanya berlaku bagi orang yang tinggal jauh dari tempat pelaksanaan shalat Idain dan tidak berlaku kerukhshahan bagi orang yang bertempat tinggal di perkotaan atau dekat dengan tempat pelaksanaan shalat 'Idain. ${ }^{39}$

Begitu juga menurut Jumhur Ulama, bahwa tidak ada kebolehan dalam meninggalkan shalat Jum'at, walaupun bertepatan pada hari 'Idain dan tetap wajib hukumnya melaksanakan shalat Jum'at. ${ }^{40}$

Bagitu juga menurut Imam al-Nawawi dalam kitab al-Mazhab fi alFiqh al-Syafi'i li al-Sairaziy mengatakan, jika hari raya 'Idain bertepatan pada hari Jum'at, maka penduduk kampung yang jauh dari tempat pelaksanaan shalat 'Idain yang telah hadir untuk melaksanakan shalat 'Idain, maka ia boleh kembali ke kampungnya, dan boleh meninggalkan shalat Jum'at. ${ }^{41}$

Usman bin Affan sebagaimana dikutip oleh Imam al-Nawawiy juga menjelaskan di dalam khutbahnya: "Wahai manusia, sesungguhnya pada hari ini telah berkumpulnya dua hari raya dalam satu hari, maka siapa yang ingin melaksanakan shalat Jum'at bagi penduduk yang jauh tempat tinggalnya dari pelaksanaan shalat Jum'at, maka shalat-lah, dan siapa yang ingin kembali ke kampungnya, maka kembalilah, tetapi tetap melaksanakan shalat Zhuhur. ${ }^{42}$

Dari pemahaman ulama di atas dapat penulis simpulkan, bahwa shalat Jum'at yang bertepatan pada hari raya 'Idain, ada dua pendapat ulama dalam

38 Muhammad bin Idris al-Syafi'i, Al-Uum, (Beirut: Darl Al-Kutb al-Ilmiah, 1993).,., Bab Al-Idain

39 Muhammad Hasbi Ash-Shiddieqy, Hukum-hukum Fiqh Islam (Tinjauan Antar Mazhab), (Semarang: PT. Pustaka Rizki Putra, 2001), edisi ke-2., h., 93.

40 Abu Malik Kamal bin al-Sayid Salim, Shahih Fiqih Sunnah, (Judul asli: Shahih Fiqh al-Sunnah wa Adillatuhu wa Taudhih Madzahaib al-A'immah), (Penerjemah: Bangun Sarwo Aji Wibowo, dkk), (Jakarta: Pustaka Azzam, 2008)., Cet., ke-3., h., 920.

${ }^{41}$ Abu Ishaq Ibrahim bin Ali bin Yusuf al-Fairuzabadi Asy-Syirazi Asy-Syafi'i, al-Muhazzab fi Fiqh Imam al-Syafi'i, (Beirut: Al-Kutub al-Ilmiah, tt).

${ }^{42}$ Ibid. 
memahami hadis tersebut, yaitu pendapat pertama, bolehnya meninggalkan shalat Jum'at yang bertepatan pada hari raya 'Idain bagi umat Islam yang tinggalnya diperkampungan, perdesaan dan jauh dari tempat pelaksanaan shalat 'Idain, sehingga mereka kembali ke kampung halamannya dan boleh meninggalkan shalat Jum'at, namun tetap wajib hukumnya melaksanakan shalat Zhuhur sebagaimana kewajiban bagi umat Islam lainnya yang tidak melaksanakan shalat Jum'at. Pendapat yang kedua, yaitu tetap wajib hukumnya melaksanakan shalat Jum'at dan tidak berlaku ke-rukhshah-an pada hari itu, walaupun shalat Jum'at bertepatan pada hari 'Idain. Begitu juga bagi seorang Imam shalat, ia tetap wajib hukumnya melaksanakan shalat Jum'at. Karena jika ada yang berkeinginan melaksanakan shalat Jum'at atau yang belum melaksanakan shalat 'Idain, maka bagi seorang Imam tersebut wajib hukumnya mengimami orang yang hendak melaksanakan shalat Jum'at.

\section{Kesimpulan}

Hadis yang menjelaskan tentang adanya kebolehan dalam meninggalkan shalat Jum'at berkualitas dhaif dari segi sanadnya dan bertentangan dengan makna ayat Al-Qur'an surat al-Jum'ah:9 dari segi matannya. Tetapi jika dirujuk kepada pemahaman para ulama terkait dengan hadis adanya kerukhsahan meninggalkan shalat Jum'at yang bertepatan pada hari raya Idain, maka para ulama sepakat bahwa meninggalkan shalat Jum'at tanpa ada uzur syar'i adalah dilarang dan pelaksanaan shalat Idain tidak dapat membatalkan kewajiban seorang muslim dengan melaksanakan shalat sunnah. Dan jika dirujuk kembali terkait asbab al-Wurud hadis tersebut sehingga adanya kerukhsahan meninggalkan shalat Jum'at yang bertepatan pada hari Raya Idain dikarenakan jarak yang jauh antara perkampungan dengan pelaksanaan shalat Jum'at, sehingga diberikan keringanan untuk tidak melaksanakan shalat Jum'at dan tetap melaksanakan shalat Zhuhur.

Selain itu, jika ditinjau pada zaman sekarang, maka makna hadis tersebut sangat sulit sekali ditemukan, disebab pada zaman sekarang di setiap lurah, Jorong atau pun perkampungan telah memiliki masjid dengan fasilitas yang lengkap, sehingga tidak ada lagi kebolehan dalam meninggalkan shalat Jum'at walaupun bertepatan pada hari 'Idain, selain ada udzur syar'i lainnya, seperti Musafir, Sakit, Hujan dan sebagainya. 
256 | FOKUS : Jurnal Kajian Keislaman dan Kemasyarakatan Vol. 5, No. 2, 2020

\section{Daftar Pustaka}

Abdullah bin Bahar Amr al-Darimi, Al-Amamar Abi Muhammad. Sunan alDarimi. Bairut: Dar al-Fikr, 1426.

Abi al-Hajjaj Yusuf al-Maziy, Al-Hafidz Jamaluddin. Tahzib al-Kamal $f i$ Asma'i al-Rijal, Beirut, Darl Al-Fikri, 1426

Ahmad bin Su'ib bin Ali al-Khurasaniy al-Nasa'i,Al-Imam Al-Hafiz Abi Abdurrahman. Sunan Al-Nasa'i. Beirut, Darl kitab al-Ilmiah, 1426.

Al-Bassam, Abdullah bin Abdurrahman. Syarah Bulughul Maram, (Penerjemah: Aan Anwariyah dkk), (judul asli: Taudhih Al-Ahkam min Bulugh Al-Maram). Jakarta, Pustaka Azzam, 2006.

Ash-Shiddieqy, Muhammad Hasbi. Hukum-hukum Fiqh Islam (Tinjauan Antar Mazhab). Semarang, PT. Pustaka Rizki Putra, 2001.

Aziz Ali Mubarak, Faishal bin Abdul. Ringkasan Nailul Authar (judul asli: Bustan al-Ahbari Muhthashari Nail al-Authar). (Penerjemah: Amir Hamzah Fakhruddin, dkk), Jakarta Selatan, Pustaka Azzam, 2006.

Ahmad bin Usman al-Zahabiy, Abi Abdillah Muhammad. Mizan I'tidal, Beirut, Darl Al-Fikri, 1426.

Departemen Agama RI, al-Qur'an dan Terjemahannya. Bandung, Diponegoro, 2010.

al-Fairuzabadi Asy-Syirazi Asy-Syafi'i, Abu Ishaq Ibrahim bin Ali bin Yusuf. al-Muhazzab fi Fiqh Imam al-Syafi'i. Beirut, Al-Kutub al-Ilmiah, tt.

Hanbal bin Hilal bin Asad bin Idris, Ahmad bin Muhammad bin. Musnad Ahmad bin Hanbal. Bairut, Dar al-Fikr, 1426.

Hassan, A. Qadir. Ilmu Mushthalah Hadits. Bandung, CV Diponegoro, 1996.

Jalaluddin As Syuyutiy, Al-Hafidz. Asbab Wurud al-Hadits, (Pentahqiq: Dr. Yahya Ismail). Beirut, Darl Al-Kutub, 1985.

Isa bin Saurah al-Tirmizi, Muhammad bin. Sunan al-Tirmizi. Bairut, Darl Fikr, 1426.

Kamal bin al-Sayid Salim, Abu Malik. Shahih Fiqih Sunnah, (Judul asli: Shahih Fiqh al-Sunnah wa Adillatuhu wa Taudhih Madzahaib al- 
A'immah), (Penerjemah: Bangun Sarwo Aji Wibowo, dkk). Jakarta, Pustaka Azzam, 2008.

Khairuddin. "Studi Kritik Hadis tentang Melaksanakan Shalat Jum'at pada Waktu Hari Raya". Al-Fikra: Jurnal Ilmiah Keislaman, Vol.11, No.1 (2012). https://ejournal.uin-suska.ac.id.

al-Khathib, Muhammad 'Ajjaj. Ushul Hadits: Ulumul wa Mushthalahuhu. Bairut: Darl Al-Fikri, 1429.

Muhammad Azzam, Abdul Aziz. dkk, Fiqh Ibadah. Jakarta, Amzah, 2013.

Muhammad bin Yazid al-Qazwiniy, Al-Hafidz Abi Abdullah. Sunan Ibn Majah. Bairut, Dar al-Kutb al-Ilmiah, 1426.

Qayim al-Jauziyah, Al-Hafizh Ibn. Aun al-Ma'bud Syarah Sunan Abi Daud. Bairut, Dar al-Fikr, 1426.

Rizal, Amnu. Hukum Salat Jum'at bertepatan pada Hari Raya (Studi Komparatif antara Mazhab Syafi'i dan Mazhab Hanbali). https://repository.ar-raniry.ac.id.

Sabit, Sayyid. Fiqh Sunnah. Kairo, Dar al-Fath, t. th.

Sulaiman bin al-As'as al-Sajistaniy, Al-Imam al-Hafiz Abu Daud. Sunan Abi Daud. Bairut, Darl al-Kitab al-Ilmiyah, 1426.

al-Syafi'i, Muhammad bin Idris. Al-Uum. Beirut, Darl Al-Kutb al-Ilmiah, 1993.

Tim Ahli Tafsir, Shahih Tafsir Ibnu Katsir. (Penerjemah: Tim Pustaka Ibnu Katsir, Judul Asli: Al-Misbaahul Muniir fii Tahdziini Tafsiiri Ibni Katsiir). Jakarta, Pustaka Ibnu Katsir, 2018.

Wensinck, A.J. al-Mu'jam al-Mufahras li al-Fazh al-Hadits al-Nabawiy al-Kutub al-Sittah wa 'am musnad al-Darimi wa muwatta' al-Malik wa Musnad Ahmad bin Hanbal. Istanbul, Darul al-Dakwah, 1986.

Yunus, Mahmud. Kamus Arab-Indonesia. Jakarta, PT Mahmud Yunus Wa Dzurriyyah, 2010.

Zuhdi Anwar, Muhammad. Pemahaman Hadis 'Idain di Hari Jum'at (Pendekatan Ma'anil Hadis). https://core.ac.uk. 
258 | FOKUS : Jurnal Kajian Keislaman dan Kemasyarakatan Vol. 5, No. 2, 2020

Halaman ini dikosongkan 